\title{
CHALLENGES IN HUMAN RESOURCE MANAGEMENT IN THE CULTURE INDUSTRY IN LATVIA
}

\author{
*Sanita Bethere, Lasma Licite-Kurbe \\ Latvia University of Life Sciences and Technologies, Latvia \\ *Corresponding author's email: sanita.bethere@gmail.com
}

\begin{abstract}
The culture industry and its human resources have been little researched in Latvia, yet research on the culture industry is important, because the industry makes a significant contribution to economic growth by promoting employment and the development of competitive regions. The culture industry encompasses libraries, folk art, theatre, music, museums, the creative industry and other sub-industries, yet in recent years those working in all the culture subindustries faced various challenges, including: a low remuneration and insufficient monetary and non-monetary bonuses, resulting in lower job satisfaction and a high personnel turnover. Accordingly, the aim of the research is to develop recommendations for hiring and retaining human resources by examining challenges in managing human resources in the culture industry. The authors conducted a survey among the personnel of the Board of Culture of Jelgava municipality. The survey found that the main challenges faced by the administration of the Board of Culture were an uncompetitive remuneration, the aging of the personnel and generational change as well as inefficient and insufficient motivation for working. The research has developed two scenarios for recruiting: 'promotion of creativity and non-monetary motivation' that aim to publicly appreciate human resources, so that they would feel important and significant as well as facilitate creativity, innovation and collective solidarity, while for the purpose of retaining human resources in a long-term and decreasing their turnover, the second scenario 'competitive remuneration and the differentiation by position category' aims to gradually raise the remuneration and differentiate it for all categories of personnel.
\end{abstract}

Key words: culture industry, human resources, motivation.

\section{Introduction}

The culture industry is one of the fastest growing industries, and the value added of the culture industry is almost more than $10 \%$ of GDP in developed countries (Shu-sheng, 2012). However, the culture industry and its contribution to the national economy has been relatively little researched; besides, the scope of the research has been narrow. Compared with other industries of the national economy of Latvia, only indirect attention has been paid to it. Nevertheless, research on the culture industry is important, as it is not only a consuming industry - the industry considerably contributes to economic growth (Yusof et al., 2013; Bandelj \& Morgan, 2015; Greffe, 2016), thereby increasing employment (Marcen, 2014; Schaufeli, 2018; Bryan et al., 2000), the development of innovative products (Yusof et al., 2013), development of R\&D investment (Varsakelis, 2001) as well as the development of competitive regions (Bille \& Schulze, 2006). In addition, culture plays an important role in performing various social functions - the culture forms the system of individual and societal values, knowledge and skills, experience (Santoso \& Schrepp, 2019), promotes local community development and identity formation (Ministry of Culture, 2014), as the culture industry is broad in scope, encompassing libraries, folk art, theatre, music, museums, the creative industry and other sub-industries. Not only an individual's personality and life quality but also the growth of the society, regions and the country depend on the diversity, richness and accessibility of the cultural environment and the participation of active and creative individuals in the development of it (Ministry of Culture, 2014). Through art, it is possible to express the moods of society and create common values. Culture is the only source of human values (Rifkins, 2004).

Although scientific research has emphasized the importance of culture in the development of any country and nation, the culture industry in Latvia faces various challenges that have a significant impact on the development of human resources in this industry. The Cultural Policy Guidelines 2014-2020 'Creative Latvia' identified several challenges in the culture industry, incl. - no targeted research and economic effect assessment of the creative industries sector and a lack of funding for the sphere of culture. As a result of the economic crisis, funding for culture has been significantly reduced, which has affected support for the creative process. Although there are opportunities to diversify sources of finance, given the small market and limited financial capacity of the population, there is still a need for government support for preserving cultural capital and providing cultural institutions with a basis for developing new initiatives to maintain the national identity and value in the society. It should also be taken in consideration that access to finance and support for the culture industry as a whole have a significant effect on the availability and development of human resources in the culture industry.

The present research therefore aims to develop recommendations for hiring and retaining human resources by examining challenges in managing human resources in the culture industry. To achieve 
the aim, the following specific research tasks have been set: 1) describe challenges in managing human resources in the culture industry; 2) develop scenarios for recruiting and retaining human resources for the Board of Culture of Jelgava municipality.

\section{Materials and Methods}

To analyse trends in the culture industry in Latvia in the context of human resources, statistical analysis was employed, while a survey and interviews with three experts of the culture industry were used to identify challenges in human resource management in the culture industry. The target population was the personnel of the Board of Culture of Jelgava municipality aged 19-86 (133 employees). The Board of Culture was selected as the research object because in 2019 its 133 personnel worked in 14 cultural centres, 22 public libraries and 98 folk art and craft or amateur groups, thereby representing the human resources of various fields of culture, as well as it is a regional institution, which at the same time reveal challenges in the regions of Latvia in terms of human resources in the culture industry. The total number of respondents was 107 , which means that totally $80 \%$ of the personnel of the Board of Culture completed their questionnaires. Given the diversity of the culture industry, the survey examined the human resources of the culture industry in the context of three personnel categories: creative personnel (leaders of amateur art groups, concertmasters, choir masters and other specialists, genre leaders, sound and light operators), cultural personnel (administrators, cultural supervisors and event organizers) and library personnel (library heads, librarians and a local history specialist). The research used the scenario method to determine the ways of recruitment and long-term retention of human resources for the Board of Culture.

The research analysed research papers of international scientific journals on the role of culture, research studies conducted by the Ministry of Culture, data of the Central Statistical Bureau, internal and external legal documents of the local government of Jelgava municipality and the legal framework of the Republic of Latvia.

\section{Results and Discussion}

Challenges in human resource management in the culture industry. The analysis of the survey data on motivational factors for human resources (Figure 1) allows concluding that the most important factor $(57 \%$ of the respondents indicated it as the first priority) was an interesting, creative and meaningful job, while a competitive remuneration was mentioned as the second most important factor $(16 \%$ of the respondents mentioned it as the first priority). The professionals of all the backgrounds - creative, cultural and library - agreed with the role that was played by meaningful work.

The cultural experts interviewed also point out that a competitive remuneration was one of the most important motivational factors; however, it should be taken into consideration that "the attitude towards work is encoded in a man and not in a competitive remuneration, and high salaries combined with poor

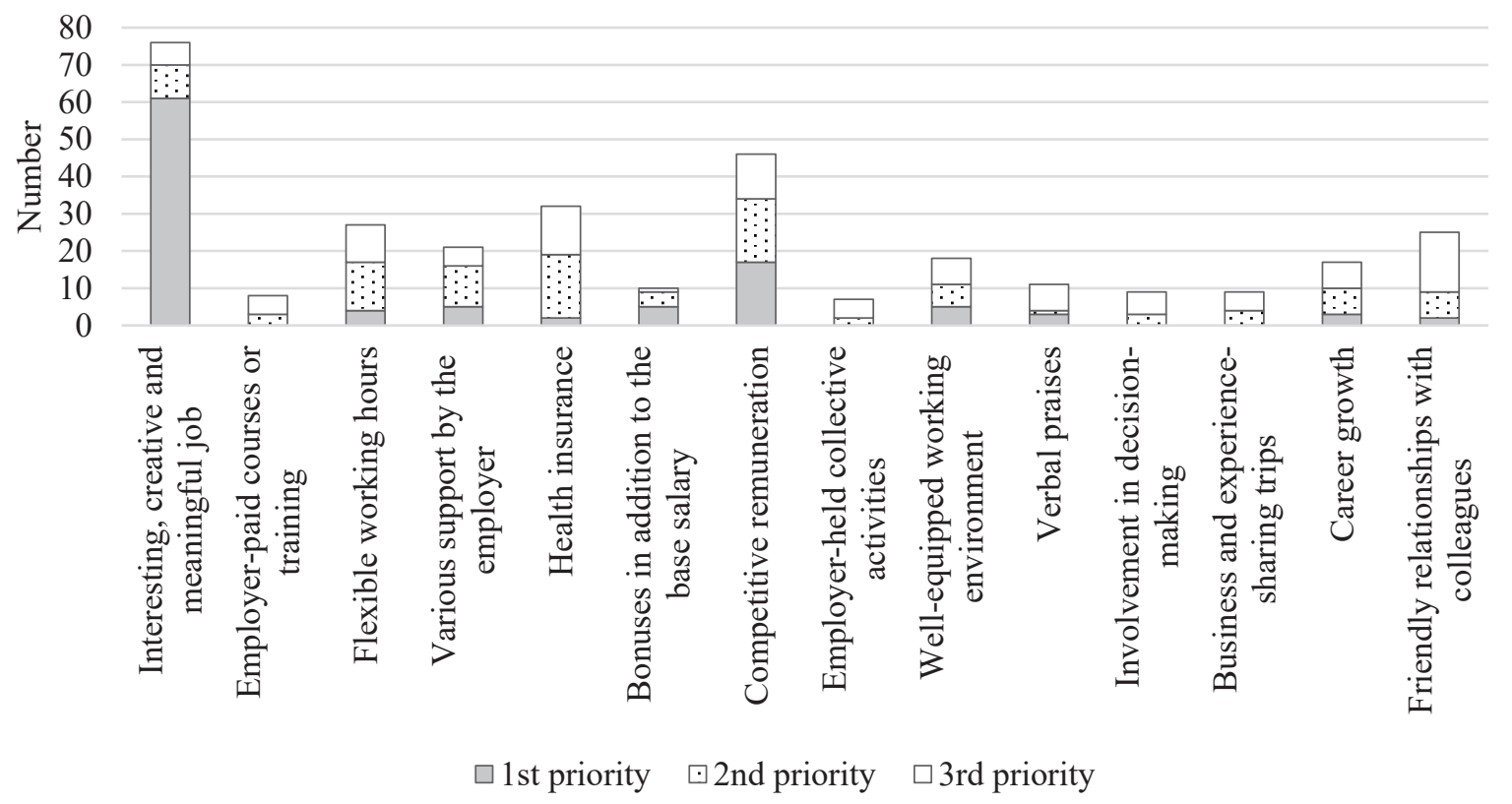

Figure 1. Distribution of motivational factors for the human resources of the Board of Culture by priority.

Source: authors' construction based on the survey of personnel of the Board of Culture of Jelgava municipality, 2019 $(n=107)$. 


\section{Average monthly gross salaries of employees in municipal institutions in Latvia and Jelgava municipality by kind of activity in the period 2015-2018, EUR}

\begin{tabular}{|c|c|c|c|c|c|}
\hline Kind of activity & 2015 & 2016 & 2017 & 2018 & $2018 / 2015, \%$ \\
\hline \multicolumn{7}{|c|}{ Latvia } \\
\hline $\begin{array}{c}\text { Art, entertainment and recreation } \\
\text { Creative, artistic and entertainment activities }\end{array}$ & 586 & 617 & 660 & 712 & 21.5 \\
\hline $\begin{array}{c}\text { Libraries, museums and activities of other } \\
\text { cultural institutions }\end{array}$ & 576 & 604 & 639 & 689 & 19.6 \\
\hline \multicolumn{7}{|c|}{ Jelgava municipality } & 621 & 669 & 720 & 22.2 \\
\hline \begin{tabular}{c} 
Libraries \\
\hline
\end{tabular} & 531 & 523 & 538 & 571 & 7.5 \\
\hline Creative personnel (amateur art groups) & 704 & 699 & 694 & 725 & 3.0 \\
\hline Cultural institutions & 554 & 583 & 618 & 689 & 24.3 \\
\hline
\end{tabular}

Source: authors' own compilation based on data of the Central Statistical Bureau and documents of the Personnel Department of Jelgava municipality, 2015-2018.

management will only be motivational in a shortterm'. Nevertheless, the experts overall acknowledged that one of the most important problems in the culture industry was the low remuneration. As a result of the economic crisis, funding for the culture industry, including salaries for those working in the culture industry, was considerably reduced, which increased the risk of losing professional specialists in the labour market as well as a high employee turnover in organizations, especially in the regions of Latvia (Table 1).

As shown in Table 1 , the average monthly gross salary in the field of art, entertainment and recreation in municipal institutions was EUR 712 in 2018, and compared with 2015 , it rose by $21.5 \%$. In Jelgava municipality, the average monthly gross salary in the same field totalled EUR 662 in 2018; compared with the national average, it was 7\% lower. In 2018 in Jelgava municipality, the lowest average monthly gross salary in the culture industry was reported for librarians, at EUR 571. In the period 2015-2018, the average monthly gross salary of creative personnel varied, which could be explained by the changing numbers of amateur art groups and their leaders.

The survey found that the available monetary and non-monetary bonuses are taken for granted, being not motivational, by employees, and are consequently underestimated.

In accordance with the Law on Remuneration of Officials and Employees of State and Local Government Authorities, the following monetary and non-monetary bonuses are available for the human resources of the Board of Culture of Jelgava municipality: social security, a steady and regular remuneration, paid health insurance policies, a compulsory health check every three years, a bonus of up to $20 \%$ of the basic monthly salary if the employee, in addition to the direct duties, replaces a personnel member being absent or takes an unfilled vacancy or performs other duties, as well as various benefits. In addition to the mandatory additional leave provided for by the Labour Law, the employee is granted one to three working day additional leave if the employee cares for one or more children under the age of 16 or a disabled child under the age of 18, as well as paid holidays (one holiday on the first day of school due to commencement of the child's schooling in years 1-4, not more than three holidays due to marriage and one holiday on the graduation day when the employee or his/her child graduates from an educational institution) as well as training leave with the pay for the time of the leave. However, the respondents emphasized the importance of non-monetary motivational factors an opportunity to get regular feedback and praises for well-done work. The results of the survey also showed that the employees preferred a democratic management style and a friendly atmosphere in the team. This was also confirmed by the experts that 'it is very important for the manager to know what the employees think, make to some extent a joint decision and seek to decide collectively, thereby promoting the collective responsibility for the work and ongoing processes'.

An important challenge faced by the Board of Culture in the context of human resources is personnel ageing and generational change. The personnel of the Board of Culture of Jelgava municipality are represented by four generations. The most personnel were aged 55-74 (54 personnel) and 38 were aged less than 54 (52). There were 23 younger employees (aged 19-37). The longest employment relationship was 38 years. One can conclude that there is a risk of failure to replace the human resources in the coming years. Library personnel in particular could be most significantly affected by the replacement of the personnel, as part of them were of pre-retirement 
or retirement age. Besides, younger personnel tend to leave the Board of Culture more often than others because of a low remuneration and often because of the specifics of the culture industry, e.g. being a cultural employee often involves working in evenings and on weekends. As a result, if employees do not receive a competitive and motivational remuneration, they more often decide to change their jobs. Furthermore, there is also a lack of qualified specialists among creative personnel. Creative personnel work part-time, resulting in a low and non-motivational remuneration. Twenty five creative personnel took several part-time positions (were leaders of several amateur art groups), which could be explained by a lack of qualified specialists in the vicinity of Jelgava municipality and Jelgava city. However, to attract qualified specialists, a competitive remuneration has to be paid because no employee wants long-term employment based on enthusiasm and for a low remuneration.

In view of the fact that the challenges identified in human resource management related to employee motivation, the research developed two scenarios for recruiting and retaining human resources for the Board of Culture, taking into account the problems identified.

Scenarios for recruiting and retaining human resources in the culture industry. Scenario 1: Promotion of creativity and non-monetary motivation. In the interview, one of the cultural experts states that one of the employer's challenges is to ensure that 'the employee does not lose motivation to perform the job duties at high quality and productivity, as well as grow and develop professionally. Therefore, efforts have to be made to develop the willingness of employees to work with creativity'. This was also confirmed by another expert interviewed who stressed the importance of working on raising employee selfesteem. The results of the survey also showed that it was important for the employees to feel important and valued as well as receive regular feedback and verbal praises for well-done work.

Since the survey revealed that praises and appreciation were important to the employees (44\% of the respondents said they would appreciate public praises and appreciation for their work), the authors suggest introducing a thank you event once a year, which honours the employees who have achieved high performance during the year. It would be an opportunity to give verbal praises and give thanks (which is an important form of appreciation for some employees). This kind of event would allow employees to feel their significance.

To encourage creative inspiration and enthusiasm among employees, it is suggested to organize summer or winter creative camps to unleash creativity in them. This is a way how to unite groups of employees, promote a positive atmosphere among the colleagues and develop mutual cooperation, so that the employees feel united. According to the survey, 77\% of the respondents supported employer-held non-work activities, excursions and other collective activities.

To unleash creativity and satisfy the aspirations of cultural personnel for achievements, the authors suggest holding a scenario development and implementation competition that would serve as one of the motivational factors, as it enables the employees to prove themselves as well as unleashes creativity in them. This is important because $86 \%$ of the respondents said that achievements were important to them. For the administration, however, this is essential because it allows assessing the creativity of employees and the quality of events held in cultural centres. The competition would award a cash prize for three cultural supervisors whose scenarios written and their implementation in a particular event have been appreciated the most.

A good way to motivate and assess personnel and broaden their views is to reimburse their expenses on experience-sharing trips abroad. This is one of the motivational factors that attract younger employees, as well as a good way to motivate and appreciate the employees who make a significant personal contribution to their job responsibilities. An opportunity for going abroad for sharing experience could be given to two employees based on their performance evaluation for a reporting period.

Scenario 2: Competitive remuneration and the differentiation by position category. The results of the survey confirmed that the employees were motivated by meaningful, interesting and creative work and a competitive remuneration. Although various monetary and non-monetary bonuses are available to the personnel of the Board of Culture of Jelgava municipality, which partly offset the low and uncompetitive remuneration, it has to be taken in account that the bonuses alone are not enough. It is important to emphasize that all the personnel are currently eligible for a remuneration adjustment based on the job classification, thereby providing equal pay for equal work. Based on the survey conducted and available information on personnel remuneration, it is necessary to develop a competitive remuneration system for each category of job positions.

Creative personnel - leaders of amateur art groups in each genre receive equal pay in accordance with the job category established. However, the remuneration differentiation according to the results achieved in shows, the amateur art category and overall performance is necessary. At present, creative personnel are not included in the common evaluation system of the local government of Jelgava municipality, as it is not correct to evaluate the performance of 
creative personnel according to the same principles as 'standard' full-time employees. The specifics of work done by creative personnel and the achievable results against which they could be evaluated are different. Therefore, it is necessary to develop a set of rules for the remuneration of amateur art groups and creative personnel, which includes the principles ensuring the traceability of remuneration components and calculations as well as a consistent approach to setting remuneration. Once a year, it would be necessary to perform an evaluation of the performance of an amateur art group and its leader, which would involve identifying the category of the amateur art group and evaluating the individual contribution of the amateur art group's leader. In accordance with the set of rules established, the remuneration of an amateur art group would consist of the basic rate and the variable rate (fixed or variable bonuses of up to $20 \%$ of the monthly salary for the position, depending on participation in activities of various levels and types (shows, competitions, festivals etc.) and other bonuses (if any)).

The amount of remuneration has to be set in order to be commensurate with the remuneration for equal work. Totally, the set of rules defines three remuneration categories: Category 1 for choirs, dance ensembles and orchestras; Category 2 for folklore and folk music groups, vocal ensembles, amateur theatres, folk applied art groups; Category 3 for world-level contemporary dance groups, pop bands, theatre sport groups and other non-folk art groups. Each category is subdivided into three employee categories and four amateur art group categories. The categorization of employees and amateur art groups is done according to performance evaluation results. The basic salary rate is determined based on the categories of personnel and amateur art groups, to which, according to performance evaluation results, a variable rate not exceeding $20 \%$ of the monthly salary rate is applied. The set of rules governing the activities of amateur art groups and setting remuneration for creative personnel could serve as a powerful motivational tool to motivate, hire and retain creative personnel not only in the institution researched but also in other similar organizations.

The cultural personnel are also paid the same salary for performing the same duties. An analysis of the contributions of cultural supervisors and event organizers in respect to their duties performed allows concluding that their contributions differ significantly. Accordingly, it is necessary to consider the possibilities of differentiating the remuneration of this personnel. By taking into consideration the occupancy of cultural centres, the number and variety of events organized by cultural directors, as well as the number of amateur art groups operating in a particular rural community centre, it is necessary to differentiate the remuneration of cultural personnel into three categories:

- Category 1 - a lot of events and activities are held at cultural centres, a large number of events are organized and a variety of activities are offered to residents; the number of amateur art groups is from 7 to 12 ;

- Category 2 - a medium number of activities are held at cultural centres, a medium number of events are organized and the range of events is not increased (mostly uniform events that are repeated every year); the number of amateur art groups is from 5 to 7 ;

- Category 3 - a relatively small number of activities are held at cultural centres, a small number of events are organized; the number of amateur art groups is less than 5 .

It is important to evaluate an employee's performance and personal contribution as well as effectiveness. Remuneration differentiation is one way how to evaluate each employee. It should be understood that the categorization of cultural personnel also helps to determine the amount of work involved. Besides, it is important to evaluate the individual contribution to the event, whether the cultural supervisor creates scenarios for an event and conducts it himself or herself, or outsourcing opportunities saving the supervisor's personal time are used. The categorization of cultural personnel would need to be reviewed once a year according to the work done during the reporting period and the number of amateur art groups operating in the cultural centre. Taking into account the current remuneration of cultural personnel, which is, on average, EUR 689 and the basic monthly salary for 2020 estimated at EUR 976.46, the authors of the present research believe that the average monthly salary of cultural personnel in 2020 should reach at least EUR 892, and it is necessary to increase it to a competitive level.

The remuneration of library personnel is uncompetitive, which could create a major challenge to attracting new and qualified professionals in the future. The most aged personnel are found among the library personnel in particular; consequently, several personnel members are expected to retire soon. At present, the library personnel is divided into three categories, and a monthly salary is set for each category. To date, the library personnel have been categorized according to the number of registered readers in the library:

- Category 1 includes the largest rural libraries in terms of number of registered readers - over 401 registered readers;

- Category 2 includes rural libraries with a number of registered readers from 201 to 400;

- Category 3 includes rural libraries with a number of registered readers less than 200. 


\section{Scenarios for recruiting and retaining human resources for the Board of Culture of Jelgava municipality}

\begin{tabular}{|c|c|c|c|c|}
\hline Scenario & $\begin{array}{l}\text { Problems } \\
\text { identified }\end{array}$ & Solutions & Brief description & $\begin{array}{c}\text { Expected cost a year, } \\
\text { EUR }\end{array}$ \\
\hline \multirow{4}{*}{$\begin{array}{l}\text { Scenario 1: } \\
\text { Promotion of } \\
\text { creativity and } \\
\text { non-monetary } \\
\text { motivation }\end{array}$} & $\begin{array}{l}\text { Need for } \\
\text { personnel to feel } \\
\text { important and } \\
\text { significant; } \\
\text { Lack of public } \\
\text { praises }\end{array}$ & Thank you event & $\begin{array}{l}\text { Implemented once a year to honour } \\
\text { employees for their outstanding merits }\end{array}$ & $\sim 2000$ EUR \\
\hline & $\begin{array}{c}\text { Lack of } \\
\text { creativity and } \\
\text { innovation }\end{array}$ & Creative camps & $\begin{array}{l}\text { Implemented once a year to contribute } \\
\text { to innovation and team consolidation }\end{array}$ & $\sim 2000$ EUR \\
\hline & $\begin{array}{l}\text { Lack of } \\
\text { innovation and } \\
\text { routine }\end{array}$ & $\begin{array}{l}\text { Event scenario } \\
\text { development and } \\
\text { implementation } \\
\text { competition }\end{array}$ & $\begin{array}{l}\text { Implemented once a year to contribute } \\
\text { to creativity and the quality of events }\end{array}$ & $\begin{array}{c}\text { Money prizes: } \\
1^{\text {st }} \text { place }- \text { EUR } 200 \\
2^{\text {nd }} \text { place }- \text { EUR } 150 \\
3^{\text {rd }} \text { place }- \text { EUR } 100\end{array}$ \\
\hline & $\begin{array}{c}\text { Lack of } \\
\text { motivational } \\
\text { bonuses }\end{array}$ & $\begin{array}{l}\text { Experience- } \\
\text { sharing trips } \\
\text { abroad }\end{array}$ & $\begin{array}{l}\text { Implemented once a year to broaden } \\
\text { one's horizons and get inspiration }\end{array}$ & $\begin{array}{l}\text { From EUR } 200 \text { to } \\
\text { EUR } 2000\end{array}$ \\
\hline \multirow{3}{*}{$\begin{array}{l}\text { Scenario 2: } \\
\text { Competitive } \\
\text { remuneration } \\
\text { and the } \\
\text { differentiation } \\
\text { by position } \\
\text { category }\end{array}$} & \multirow{3}{*}{$\begin{array}{l}\text { Low and } \\
\text { uncompetitive } \\
\text { remuneration } \\
\text { Equal } \\
\text { remuneration } \\
\text { system is } \\
\text { applied }\end{array}$} & $\begin{array}{c}\text { Remuneration } \\
\text { system for creative } \\
\text { personnel }\end{array}$ & $\begin{array}{l}\text { A set of rules for the remuneration } \\
\text { of amateur art groups and creative } \\
\text { personnel that differentiate the } \\
\text { remuneration according to the personal } \\
\text { contribution of the employee and the } \\
\text { category of the amateur art group }\end{array}$ & $\begin{array}{l}\text { Calculations are still } \\
\text { in process }\end{array}$ \\
\hline & & $\begin{array}{c}\text { Remuneration } \\
\text { system for cultural } \\
\text { personnel }\end{array}$ & \multirow{2}{*}{$\begin{array}{l}\text { Higher remuneration and the } \\
\text { differentiation into three categories }\end{array}$} & \multirow{2}{*}{$\begin{array}{l}\text { Total funding needed } \\
\text { for raising and } \\
\text { differentiating the } \\
\text { remuneration EUR } \\
100000\end{array}$} \\
\hline & & $\begin{array}{l}\text { Remuneration } \\
\text { system for library } \\
\text { personnel }\end{array}$ & & \\
\hline
\end{tabular}

Source: authors' own compilation.

After assessing the performance of rural libraries and librarians and the librarians' personal contribution to the development and improvement of the libraries' performance, it is required improving the current system, leaving Category 1 unchanged. A large number of registered readers means more work and, after an increase in the number of registered readers, the personal contribution and performance of library personnel has to be assessed. Category 2 has to include the libraries and their personnel who, in addition to providing basic library functions and services, take part in various projects, which involves engaging various audiences in the projects and sometimes working outside normal office hours. Category 3, however, has to include all the libraries and their librarians who provide only the basic library functions and services and do not contribute to the involvement of local residents in the activities of the libraries through organizing various events and activities.

Establishing categories for library personnel would increase motivation and appreciation for those who already put a lot of efforts into their libraries, yet in those who are not active enough in this respect, a higher remuneration would arouse a wish to make their libraries perform better. Taking into account the current remuneration of library personnel, which is, on average, EUR 571 and the basic monthly salary for 2020 estimated at EUR 976.46, the authors believe that the average monthly salary of library personnel in 2020 should reach at least EUR 758, and it is necessary to continue increasing it to a competitive level. Both scenarios are summarised in Table 2.

As shown in Table 2, the largest investment is needed for Scenario 2, as the total expense exceeds EUR 100 000. Introducing Scenario 1 requires an investment in the range of EUR 4650-6650 within a calendar year. Of course, it is more cost-efficient to implement Scenario 1, yet in general long-term solutions would be needed, which in this case would be an increase in remuneration and the differentiation of remuneration. Overall, the authors recommend implementing both scenarios to the extent possible, 
as they are complementary: Scenario 1 would help to engage and motivate well-performing employees on a day-to-day basis, while Scenario 2 would promote personnel retention in a long-term.

Overall, one could conclude that the monetary and non-monetary bonuses introduced by the Board of Culture of Jelgava municipality are often taken for granted and not sufficiently appreciated by the employees. It is quite difficult to vary motivational tools because the Board of Culture is governed by the Law on Local Governments and the Law on Remuneration of Officials and Employees of State and Local Government Authorities. However, this does not exclude a possibility for the administration of the Board of Culture to seek solutions in order to supplement non-monetary bonuses with significant work experience-sharing trips within Latvia or abroad. Such trips not only broaden the personnel's horizons but also help the personnel to appreciate their work environment and the bonuses available to them.

\section{Conclusions}

1. In accordance with the national legal framework and internal legal documents of the organization, various monetary and non-monetary bonuses are available for the human resources of the Board of Culture of Jelgava municipality: social security, a steady and regular remuneration, paid health insurance policies, various benefits and additional leave. However, the mentioned bonuses are taken for granted and not sufficiently appreciated by the employees. Besides, the employees surveyed indicated the need for non-monetary bonuses - praises and appreciation. Accordingly, it is necessary to increase employees' motivation by introducing non-monetary bonuses - work experience-sharing trips within Latvia or abroad and a thank you event - which would raise their feeling of appreciation for their work, as well as holding creative camps for them.

2. One of the most important problems faced by culture industry employees in Latvia is a low remuneration. For this reason, the Board of Culture of Jelgava municipality needs to review the remuneration policy for cultural and library personnel, as the remuneration for any personnel category is currently uncompetitive. In order for personnel to be evaluated in terms of their personal contribution and performance, in every team cultural and library personnel have to be differentiated into three categories, which to the extent possible would allow differentiating monthly salaries based on the criteria set for each category. For creative personnel, however, it is important to introduce an evaluation system that objectively takes into account a personal contribution of the leader of an amateur art group and their collective achievements, thereby differentiating their monthly salaries and setting variable bonuses for their performance.

3. The Board of Culture of Jelgava municipality also faces the problem of ageing of its personnel; therefore, considerable personnel replacement is expected in the future, especially among its library personnel. To solve this problem, it is necessary to set criteria for a competitive remuneration and enhance the motivation system to attract new highly-qualified specialists.

\section{References}

Bandelj, N., \& Morgan, P.J. (2015). Culture and Economy. In J.D. Wright (Ed.), International Encyclopedia of the Social \& Behavioral Sciences (pp. 535-541). Elsevier Ltd.

Bille, T., \& Schulze, G.G. (2006). Culture in Urban and Regional Development. In V.A. Ginsburgh \& D. Throsby (Eds.), Handbook of the Economics of Art and Culture (pp. 1051-1099). North Holland.

Bryan, J., Hill, S., Munday, M., \& Roberts, A. (2000). Assessing the role of the arts and cultural industries in a local economy. Environment and Planning, 32, 1391-1408. DOI: 10.1068/a32168.

Greffe, X. (2016). From culture to creativity and the creative economy: A new agenda for cultural economics. City, Culture and Society, 7 (2), 71-74. DOI: 10.1016/j.ccs.2015.12.008.

Ministry of Culture. (2014). Kultūrpolitikas pamatnostādnes 2014.-2020.gadam 'Radošā Latvija' (Cultural Policy Guidelines 2014-2020 'Creative Latvia'). Riga. Retrieved December 30, 2019, from https://www. km.gov.lv/uploads/ckeditor/files/KM_dokumenti/Radosa_Latvija.pdf. (in Latvian).

Marcen, M. (2014). The role of culture on self-employment. Economic Modelling, 44 (1), S20-S32. DOI: 10.1016/j.econmod.2013.12.008.

Rifkins, Dž. (2004). Jaunās ekonomikas laikmets (New Economic Era). Riga: Jumava. (in Latvian).

Santoso, H.B., \& Schrepp, M. (2019). The impact of culture and product on the subjective importance of user experience aspects. Heliyon, 5 (9), 1-12. DOI: 10.1016/j.heliyon.2019.e02434.

Schaufeli, W.B. (2018). Work engagement in Europe: Relations with national economy, governance and culture. Organizational Dynamics, 47, 99-106. DOI: 10.1016/j.orgdyn.2018.01.003.

Shu-sheng, L. (2012). Culture Industry Development and Regional Economy - Case Study of Tianjin. Physics Procedia, 25, 1352-1356. DOI: 10.1016/j.phpro.2012.03.244. 
Varsakelis, N.C. (2001). The impact of patent protection, economy openness and national culture on R\&D investment: a cross-country empirical investigation. Research Policy, 30 (7), 1059-1068. DOI: 10.1016/ S0048-7333(00)00130-X.

Yusof, F., Abdullah, I.C., Abdullah, F., \& Hamdan, H. (2013). Local Inclusiveness in Culture based Economy in the Development of ECER, Malaysia: Case Study from Kelantan. Procedia - Social and Behavioral Sciences, 101, 445-453. DOI: 10.1016/j.sbspro.2013.07.218. 